\title{
Exergy analysis of Omotosho phase 1 gas thermal power plant
}

\author{
Egware Henry Okechukwu, Obanor Albert Imuentinyan
}

Department of Mechanical Engineering, University of Benin, Benin City, Nigeria

Email address:

henryegware@yahoo.com(Egware H. O.),aiobanor@yahoo.com(Obanor A. I.)

\section{To cite this article:}

Egware Henry Okechukwu, Obanor Albert Imuentinyan. Exergy Analysis of Omotosho Phase 1 Gas Thermal Power Plant. International Journal of Energy and Power Engineering. Vol. 2, No. 5, 2013, pp. 197-203. doi: 10.11648/j.ijepe.20130205.13

\begin{abstract}
This paper describes the use of exergy analysis in evaluating the performance of Omotosho Phase I Gas Thermal Power Plant. The data used were obtained from data record book. The exergy analysis, mass and energy conservation laws were applied to each component. Results obtained show that the gas turbine had the largest exergy efficiency of $96.17 \%$, while that of the total plant was $41.83 \%$, the combustion chamber had the largest exergy destruction of $54.15 \%$ while that of the total plant was $58.17 \%$.In addition, the effect of the gas turbine load variation and ambient temperature from $21^{\circ} \mathrm{C}-33^{\circ} \mathrm{C}$ are investigated. The exergy efficiency decreases and exergy destruction efficiency increases as ambient temperature increases in the plant and its components. Therefore, turbine air inlet cooling system is recommended for the plant to solve this problem.
\end{abstract}

Keywords: Exergy, Performance, Destruction, Efficiency, Power Plant, Turbine, Combustion Chamber

\section{Introduction}

Today, many managers of electrical generating utilities are striving to improve the efficiency (or heat rate) and performance of their existing thermal facility. To achieve this, the types, locations and causes of losses in the power plant have to be investigated by their thermodynamic performance. In general, energy technologies are normally examined using energy analysis. A better understanding is attained when a more complete thermodynamic view is taken, which use the Second Law of Thermodynamics in conjunction with energy analysis known as exergy analysis[1].The exergy analysis based on the Second Law of Thermodynamics should be included in order to do a complete analysis, which can also assess accurately the utilization of energy[2]. This method provides the information, which is useful for engineers, or managers to know about the power plant performance. The information obtained from the result of the analysis will form a basis for the energy manager or operation engineer to make decision on how he should operate the plant in order to save cost and energy usage.

Although the method of exergy analysis is often considered to be a new method for analyzing energy systems, the underlying fundamentals were introduced as early as the 1940's. For example a paper by [3], describes the virtue of energy which is essentially what we call "availability" [4-7] but the term most widely accepted and used in a lot of publications is "exergy". The term availability in the context of power plant may be confused with the availability of power plant or machine.

The problem of energy availability is of great importance to modern society because of its effects in the socioeconomic well-being of mankind. The growing demand for energy thus requires the integration of the problem to include both availability and its efficient usage; this implies a minimization of wastage.

The exergy of a system is defined as the maximum shaft work that can be done by the composite of the system and specified reference environment [1, 8]. The reference environment is assumed to be infinite, in equilibrium and enclosing all other systems. Typically, the environment is specified by stating, its temperature, pressure and chemical composition. Exergy is not simply a thermodynamic property, but rather is a property of both a system and the reference environment.

An exergy-based performance analysis is the performance analysis of a system based on the Second Law of Thermodynamics that overcomes the limitation of an energy-based analysis [9]. Exergy has the characteristic that it is conserved only when all processes occurring in a system and the environment are reversible. Exergy is 
destroyed whenever an irreversible process occurs[10]. When an exergy analysis is performed on a plant such as a power station, a chemical processing plant or refrigeration facility, the thermodynamic imperfections can be quantified as exergy destruction, which represents losses in energy quality or usefulness (eg. wasted shaft work). Like energy, exergy can be transferred or transported across the boundary of a system.

Exergy analysis takes into account the different thermodynamic values of different energy forms and quantities, e.g, work and heat. Exergy methods provide unique insight into the types, locations and causes of losses and can thereby help identify possible improvement. A system in complete equilibrium with environment does not have any exergy. No difference appears in temperature, pressure, concentration, etc. so there is no driving force for any process.

The exergy of a system increases the more it deviates from the environment. For instance, a specified quantity of hot water has a higher exergy content during winter than on a hot summer day. A block of ice carries little exergy in winter while it can have significant exergy in summer. Exergy is the part of energy which is useful and therefore has economic value and is worth managing carefully. Many researchers including [11-14] have conducted exergy analysis for open gas turbine power plants and calculated losses for different components using computer simulations. In their works they mentioned how the performance of the plants and its components are affected by the ambient temperature.

The exergy method of analysis overcomes the limitation of the FLT. The concept of exergy is based on both the FLT and the Second law of Thermodynamics (SLT). Exergy analysis clearly indicates the location of energy degradation in a process and can therefore lead to improved operation or technology of gas turbine plants. Exergy analysis can also quantify the quality of heat in a waste stream. The main aim of exergy analysis is to identify meaningful (exergy) efficiencies and the causes and the true magnitudes of exergy losses position and amount in the components and total plant $[12,15,16]$.

Exergy analysis is a useful method to compliment, not to replace the energy analysis. Exergy analysis has proven to be a powerful tool in the thermodynamics analysis of energy systems [16-20]. The fundamental pillar of infrastructure for other industries and for industrial growth and development depend on power generation [14]. Nigeria government have built many gas turbine power plants to meet the growing demand of electricity in the country because it's easy and low installation, availability of natural gas in the country [11]. The thermodynamic cycle upon which all gas turbines operate is called the Brayton cycle [22]. The major components of a gas turbine are compressor, combustors, turbine and generator. This paper studies exergy analysis Omotosho Phase I Thermal Power plant in Ondo State, Nigeria using the data obtained from station.

\section{Methodology}

\subsection{Data Collection}

Data used for this study were collected from the power station's $\log$ book and Omotosho Power Station Phase I Final Reportsuch as average daily power generated, mass flow rate, pressure and temperature. Relevant plant and working fluid parameters (air and fuel specific capacities and universal constants) were obtained from appropriate thermodynamic table [23].

\subsection{General Overview of Omotosho Phase I Thermal Power Station}

The Omotosho power station is located in Omotosho town, Ondo State in south - west region of Nigeria. Phase I was completed in November 2008 and currently operated by Power Holding Company of Nigeria (PHCN). Phase I has an installed generating capacity of 335 MW (8 $\mathrm{X} 41.875 \mathrm{MW}$ ). It utilizes natural gas as its combustion fuel which it gets directly through piping networks from Nigeria Gas Company (NGC); in conjunction with Shell Petroleum Development Company (SPDC) and Chevron Nigeria Limited.

The phase I power station consists of eight (8) gas turbine units each having an installed generating capacity of 42.1 MW. The units GT1, GT2, GT3, GT4, GT5, GT6, GT7 and GT8 are so named in the order of their arrangement in the power plant.

Each gas turbine unit is fired with natural gas. The eight turbines are arranged parallel in a single turbine hall, each gas turbine drives a generator with an output voltage of $10.5 \mathrm{kV}$ which is stepped up to a terminal voltage of 330 $\mathrm{kV}$, and is fed into the National Grid. The gas turbine shaft speed of 5163 revolution per minute (rpm) is reduced to $3000 \mathrm{rpm}$ of the generator by a speed reducer also stated in [24].

\subsection{Thermodynamic Operational Principle of the Plant}

It operates on open Brayton cycle and the Schematic diagram of the Plant under study is shown in Figure 1 and shows the main work and exergy flows and the state points which used in this analysis. The plant consists of an axial compressor, a combustion chamber, and gas turbine. The $\mathrm{T}$ - $\mathrm{s}$ diagram is represented in Figure 2 showing the losses due to inefficiencies of the components of actual open cycle gas turbine plant.

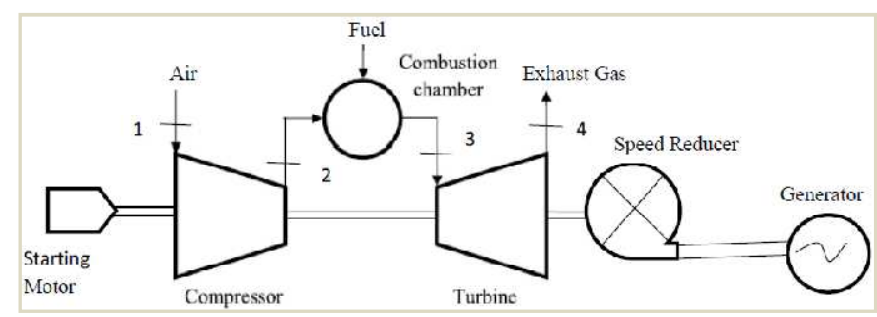

Figure 1. A Typical Schematic Diagram of Omotosho Phase I Thermal Power Plant 


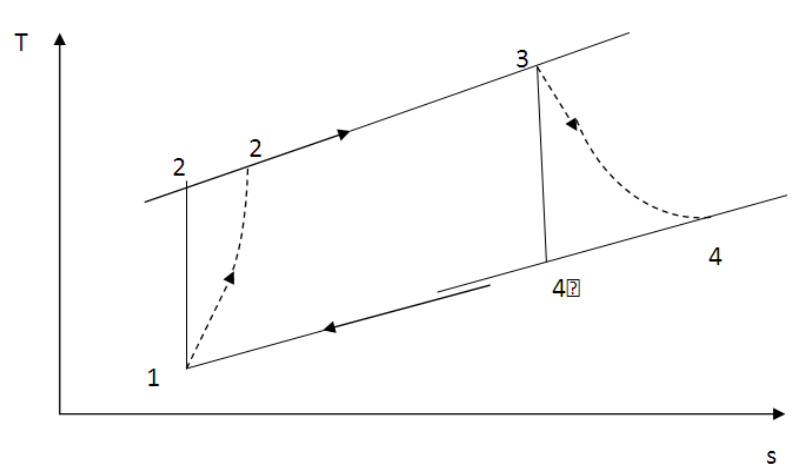

Figure 2. A Typical T-s Diagram of Omotosho Phase I Thermal Power Cycle

\subsection{Formulation of Exergy Balance Equation}

A general exergy balance equation, applicable to any component of a thermal system can be formulated by utilizing the First and Second Laws of Thermodynamics. The thermo - mechanical exergy stream may be broken down into its thermal and mechanical components [25]. The balance is given by

$$
E_{i}^{M}-E_{o}^{M}=\left(E_{i}^{T}-E_{o}^{T}\right)+\left(E_{i}^{P}-E_{o}^{P}\right)
$$

Where

$\mathrm{i}=$ exergy flow stream entering plant component

$\mathrm{o}=$ exergy flow stream leaving plant component

$\mathrm{M}=$ material component under study

$\mathrm{T}=$ thermal property

$\mathrm{P}=$ mechanical property.

The thermal and mechanical components of the exergy stream for an ideal gas with constant specific heat capacity may be written as

$$
\begin{aligned}
& \mathrm{E}^{\mathrm{T}}=\dot{\mathrm{m}} \mathrm{c}_{\mathrm{p}}\left[\left(\mathrm{T}-\mathrm{T}_{\mathrm{ref}}\right)-\mathrm{T}_{\mathrm{ref}} \ln \left(\mathrm{T} / \mathrm{T}_{\mathrm{ref}}\right)\right] \\
& \mathrm{E}^{\mathrm{p}}=\dot{\mathrm{m} R \mathrm{~T}_{\text {ref }}} \ln \left(\mathrm{P} / \mathrm{P}_{\text {ref }}\right)
\end{aligned}
$$

The entropy for each state is given by

$$
\dot{\mathrm{S}}=\dot{\mathrm{m}}\left(\mathrm{c}_{\mathrm{p}} \ln \mathrm{T} / \mathrm{T}_{\mathrm{ref}}-\mathrm{R} \ln \mathrm{P} / \mathrm{P}_{\mathrm{ref}}\right)
$$

With the decomposition defined by Equation 1, the general exergy balance equation can be expressed in [23] as

$$
\begin{aligned}
& \mathrm{ECHE}+\left(\sum \mathrm{E}_{\mathrm{i}}^{\mathrm{T}}-\sum \mathrm{E}_{\mathrm{o}}^{\mathrm{T}}\right)+\left(\sum \mathrm{E}_{\mathrm{i}}^{\mathrm{P}}-\sum \mathrm{E}_{\mathrm{o}}^{\mathrm{P}}\right)+\operatorname{Tref}\left(\sum \mathrm{Si}-\right. \\
&\left.\sum \mathrm{So}+\mathrm{Qcv} / \text { Tref }\right)=\mathrm{EW}
\end{aligned}
$$

Where

$\mathrm{E}^{\mathrm{CHE}}=$ denotes the rate of exergy flow of fuel in the plant.

$\mathrm{Q}_{\mathrm{cv}}=$ denotes the heat transfer component from the environment.

$\mathrm{E}^{\mathrm{W}}=$ denotes the net work/power of the plant.

\subsection{Exergy Balance Equations for Omotosho Phase I}

The exergy balance equation for each component in the Phase I Omotosho Power station can be derived from the general exergy balance equation given in Equation 5. The exergy balance equations for each of these components are as follows based on Figure 2:

\section{AIR COMPRESSION}

$$
\left(\mathrm{E}_{1}^{\mathrm{T}}-\mathrm{E}_{2}^{\mathrm{T}}\right)+\left(\mathrm{E}_{1}^{\mathrm{P}}-\mathrm{E}_{2}^{\mathrm{P}}\right)+\mathrm{T}_{\mathrm{ref}}\left(\dot{\mathrm{S}}_{1}-\dot{\mathrm{S}}_{2}\right)=\mathrm{W}_{\mathrm{AC}}
$$

\section{COMBUSTION CHAMBER}

$$
\begin{gathered}
\mathrm{E}^{\mathrm{CHE}}+\left(\mathrm{E}_{2}^{\mathrm{T}}+\mathrm{E}_{\mathrm{f}}^{\mathrm{T}}-\mathrm{E}_{3}^{\mathrm{T}}\right)+\left(\mathrm{E}_{2}^{\mathrm{P}}+\mathrm{E}_{\mathrm{f}}^{\mathrm{P}}-\mathrm{E}_{3}^{\mathrm{P}}\right)+\mathrm{T}_{\mathrm{ref}}\left(\dot{\mathrm{S}}_{2}+\right. \\
\left.\dot{\mathrm{S}}_{\mathrm{f}}-\dot{\mathrm{S}}_{3}\right)+\mathrm{Q}_{\mathrm{CC}}=0
\end{gathered}
$$

Where Qcc $=$ denotes the heat transfer rate between the combustion chamber and the environment.

GAS TURBINE

$$
\left(E_{3}^{\mathrm{T}}-\mathrm{E}_{4}^{\mathrm{T}}\right)+\left(\mathrm{E}_{3}^{\mathrm{P}}-\mathrm{E}_{4}^{\mathrm{P}}\right)+\mathrm{T}_{\mathrm{ref}}\left(\dot{\mathrm{S}}_{3}-\dot{\mathrm{S}}_{4}\right)=\mathrm{W}_{\mathrm{GT}}
$$

\subsection{Exergy Destruction}

Exergy is lost when the energy associated with a material or energy stream is rejected to the environment as a result of irreversibilities in the power plant.

The exergy destroyed during each process and for whole plant are written as follows:

For the compressor, Exergy destroyed, $\mathrm{E}_{\mathrm{DAC}}$

$$
\mathrm{E}_{\mathrm{DAC}}=\mathrm{T}_{\text {ref }}\left(\dot{\mathrm{S}}_{2}-\dot{\mathrm{S}}_{1}\right)
$$

For the combustion chamber, $\mathrm{E}_{\mathrm{DCC}}$

$$
E_{D C C}=E^{C H E}+\left(E_{2}^{T}+E_{f}^{T}-E_{3}^{T}\right)+\left(E_{2}^{P}+E_{f}^{P}-E_{3}^{P}\right)(10
$$

For the Gas Turbine

$$
\mathrm{E}_{\mathrm{DGT}}=\mathrm{T}_{\mathrm{ref}}\left(\dot{\mathrm{S}}_{4}-\dot{\mathrm{S}}_{3}\right)
$$

Total exergy destroyed in the plant, $\mathrm{E}_{\text {Dplant }}$

$$
\mathrm{E}_{\text {Dplant }}=\mathrm{E}_{\mathrm{DAC}}+\mathrm{E}_{\mathrm{DCC}}+\mathrm{E}_{\mathrm{DGT}}
$$

Where $E_{D A C}, E_{D C C}$ and $E_{D G T}$ represent the exergy destroyed in the air compression, combustion chamber and Gas turbine respectively.

The exergy destruction efficiency can be compared to the rate of exergy flow of fuel in the plant.

$$
\varepsilon \mathrm{D}=\frac{\mathrm{E}_{\mathrm{D}}}{\mathrm{E}^{\mathrm{CHE}}}
$$

For each of the component exergy destruction efficiencies are as follows:

For Air Compressor,

$$
\varepsilon_{D A C}=\frac{\mathrm{E}_{D A C}}{\mathrm{E}^{C H E}}
$$

For Combustion Chamber,

$$
\varepsilon_{D C C}=\frac{\mathrm{E}_{D C C}}{\mathrm{E}^{C H E}}
$$

For Gas Turbine,

$$
\varepsilon_{D G T}=\frac{\mathrm{E}_{D G T}}{\mathrm{E}^{C H E}}
$$

Exergy Destruction Efficiency, 


$$
\varepsilon_{\text {Dplant }}=\frac{\mathrm{E}_{\text {Dplant }}}{\mathrm{E}^{C H E}}
$$

\subsection{Exergy Efficiency}

Exergy efficiency is defined as the ratio of useful exergy (output) to exergy supplied (input). The exergy efficiency for a system is written as

$$
\varepsilon=\frac{\text { Useful exergy }}{\text { Exergy supplied }}=1-\frac{\text { Exergy destroyed }}{\text { Exergy supplied }}
$$

Hence, the exegetic efficiency of the gas turbine power plant is evaluated for the various components and for the overall plant from the following equations.

Air Compressor

$$
\varepsilon A C=1-\frac{E_{D A C}}{W_{A C}}
$$

Combustion Chamber

$$
\varepsilon c c=1-\frac{E_{D c c}}{E^{C H E}}
$$

Gas Turbine

$$
\varepsilon \mathrm{GT}=1-\frac{\mathrm{E}_{\mathrm{DGT}}}{\mathrm{W}_{\mathrm{GT}}}
$$

Overall Plant, $\varepsilon_{\text {plant }}$

$$
\text { Eplant }=1-\frac{\mathrm{E}_{\text {Dplant }}}{\mathrm{E}^{\mathrm{CHE}}}
$$

The formula for Chemical exergy is obtained from $[5,26]$ as shown:

Chemical exergy of fuel (methane),

$$
\mathrm{E}^{\mathrm{CHE}}=\left(1.0308+\dot{\mathrm{m}}_{\mathrm{f}}\right) \mathrm{LHV}
$$

\section{Results and Discussion}

\subsection{Results}

The data used for this analysis were obtained from the power station log between January 2008 and December

\begin{tabular}{|c|c|c|c|c|c|c|c|c|c|c|c|c|}
\hline $\begin{array}{l}\text { Power } \\
\text { (MW) }\end{array}$ & $\mathrm{T}_{1}\left({ }^{0} \mathrm{C}\right)$ & $\begin{array}{c}\mathrm{T}_{2} \\
\left({ }^{\circ} \mathrm{C}\right) \\
\end{array}$ & $\mathbf{P}_{1}$ (Bar) & $\mathbf{P}_{2}$ (Bar) & $\begin{array}{c}\mathbf{P}_{\mathrm{f}} \\
\text { (Bar) }\end{array}$ & $\begin{array}{c}\mathbf{P}_{3} \\
\text { (Bar) }\end{array}$ & $\mathbf{P}_{4}$ (Bar) & ]$_{a}(\mathbf{k g} / \mathbf{s})$ & 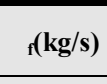 & $\bigoplus_{\text {exh }}(\mathbf{k g} / \mathbf{s})$ & $\mathrm{T}_{3}\left({ }^{0} \mathrm{C}\right)$ & $\begin{array}{c}\mathrm{T}_{4} \\
\left({ }^{\circ} \mathrm{C}\right) \\
\end{array}$ \\
\hline 39.1 & 21 & 359 & 1.013 & 11 & 17 & 11 & 1.0755 & 141.63 & 2.22 & 143.85 & 1089 & 537 \\
\hline 38.1 & 24 & 360 & 1.013 & 10 & 17 & 10 & 1.0755 & 140.19 & 2.20 & 142.39 & 1080 & 543 \\
\hline 38.0 & 25 & 361 & 1.013 & 10 & 17 & 10 & 1.0755 & 139.73 & 2.20 & 141.93 & 1083 & 543 \\
\hline 37.5 & 27 & 368 & 1.013 & 11 & 16 & 11 & 1.0755 & 138.79 & 2.18 & 140.97 & 1084 & 541 \\
\hline 36.0 & 28 & 364 & 1.013 & 10 & 16 & 10 & 1.0755 & 138.34 & 2.13 & 140.47 & 1072 & 546 \\
\hline 35.9 & 31 & 362 & 1.013 & 10 & 16 & 10 & 1.0755 & 136.97 & 2.07 & 139.04 & 1073 & 553 \\
\hline 35.1 & 32 & 372 & 1.013 & 10 & 17 & 10 & 1.0755 & 136.05 & 2.10 & 138.62 & 1076 & 545 \\
\hline 30.4 & 33 & 368 & 1.013 & 10 & 17 & 10 & 1.075 & 136.07 & 2.07 & 138.14 & 1031 & 553 \\
\hline
\end{tabular}
2011. The parameters were recorded at various average loads and ambient temperature during when each of the gas turbine units were working. A summary of the operating conditions and parameters for this period is shown in Table 1 .

Table 1. Actual performance Data for Omotosho Phase I

Table 2. Rated condition for Omotosho Phase I

\begin{tabular}{cccccccc}
\hline State & $\square(\mathbf{k g} / \mathbf{s})$ & $\mathbf{T}(\mathbf{K})$ & $\mathbf{P}(\mathbf{b a r})$ & $\mathbf{E}^{\mathbf{C H E}}(\mathbf{M W})$ & $\mathbf{E}^{\mathrm{T}}(\mathbf{M W})$ & $\mathbf{E}^{\mathbf{P}}(\mathbf{M W})$ & $\square(\mathbf{M W} / \mathbf{K})$ \\
\hline 1 & 138.53 & 300.78 & 1.01300 & 0.0000 & 0.00000 & 0.00000 & 0.00000 \\
2 & 138.53 & 637.40 & 10.2500 & 0.0000 & 15.41595 & 27.67616 & 0.01254 \\
$\mathrm{~F}$ & 2.15 & 300.78 & 16.6300 & 175.9825 & 0.00000 & 0.81613 & -0.002713 \\
3 & 140.68 & 1347.43 & 10.2500 & 0.0000 & 96.19066 & 28.39949 & 0.14776 \\
4 & 140.68 & 815.78 & 1.0755 & 0.0000 & 34.70521 & 0.73466 & 0.15867 \\
\hline
\end{tabular}

Table 3. Exergy flow rates, exergy destruction, exergetic and exergetic destruction efficiency for Omotosho Phase I

\begin{tabular}{cccccccc}
\hline Component & $\mathbf{W}(\mathbf{M W})$ & $\mathbf{E}^{\mathbf{C H E}}(\mathbf{M W})$ & $\mathbf{E}^{\mathrm{T}}(\mathbf{M W})$ & $\mathbf{E}^{\mathbf{P}}(\mathbf{M W})$ & $\mathbf{E}_{\mathbf{D}}(\mathbf{M W})$ & $\boldsymbol{\varepsilon}(\%)$ & $\boldsymbol{\varepsilon}_{\mathbf{D}}(\mathbf{\%})$ \\
\hline Compressor & -46.8651 & 0.0000 & 15.41595 & 27.67616 & 3.77302 & 91.95 & 2.14 \\
Combustion & 0.0000 & -175.9825 & 80.77471 & -0.09280 & 95.30062 & 45.85 & 54.15 \\
Chamber & & 0.0000 & -61.48550 & -27.6648 & 3.28895 & 96.17 & 1.87 \\
Gas turbine & 85.8613 & -175.9825 & 34.70520 & -0.081449 & 102.3626 & 41.83 & 58.17 \\
Total plant & 38.9962 & & & & & &
\end{tabular}

The exergy analysis results of the gas turbine unit are calculated based on the average values of the data collected as shown in Tables 1. The exergy at each state is thus calculated using state 1 as reference state and in conjuncture with the $\mathrm{T}-\mathrm{s}$ diagram of the plant shown in Figure 2. Equations $1-23$ were considered. The results are 
presented in Tables 2 and 3.

The net flow rates of various exergies crossing the boundary of each component in the gas turbine plant at operating data rated condition are shown in Table 3, together with the exergy destruction in each component. Positive values indicate the exergy flow rate of products while negative values represent the exergy flow rate of resources or fuel. Here, the product of a component corresponds to the added exergy whereas the resource to the consumed exergy [25]. The sum of the exergy flow rates products, resources and destruction equals zero for each component and for the total plant; this zero sum indicates that exergy balances are exactly satisfied.

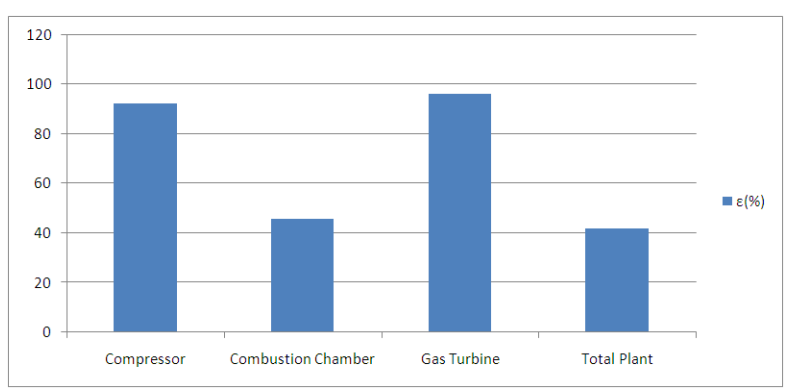

Figure 3. Exergy efficiency of components and total plant for Omotosho Phase I

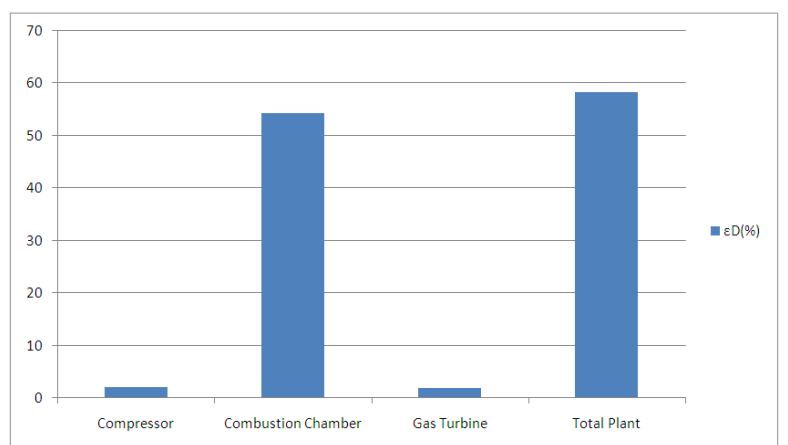

Figure 4. Exergy destruction efficiency of components and total plant for Omotosho Phase I

Exergy calculation was carried out for all the various operational values in Tables 1 using an excel spread sheet applying Equations $(6-23)$ and the summary of the calculations are presented graphically (Figures 5 -7).

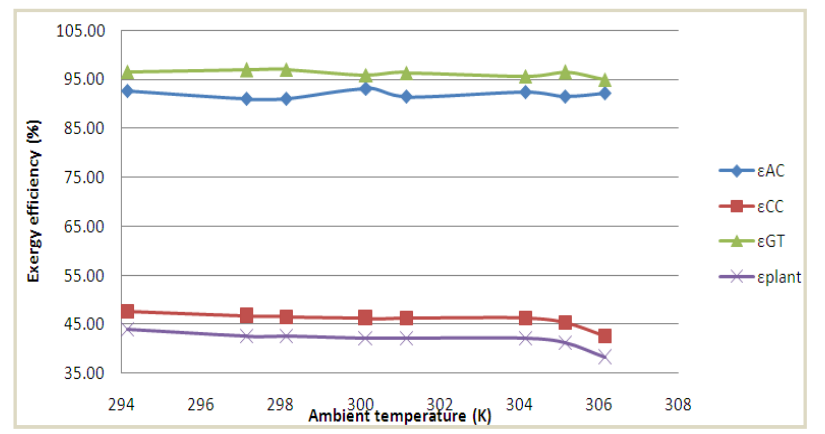

Figure 5. Change in exergy efficiency with ambient temperature for Omotosho Phase I Gas Thermal Power Plant.

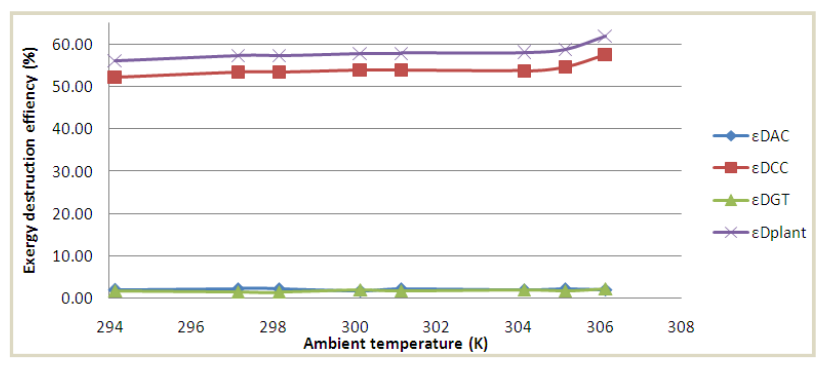

Figure 6. Change in exergy destruction efficiency with ambient temperature for Omotosho Phase I Gas Thermal Power Plant.

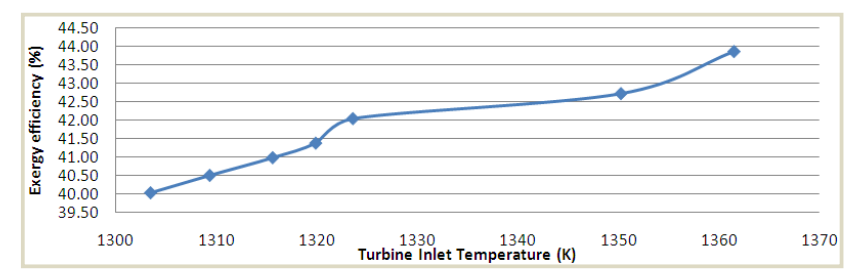

Figure 7. Change in exergy efficiency with turbine inlet temperature for Omotosho Phase I Gas Thermal Power Plant.

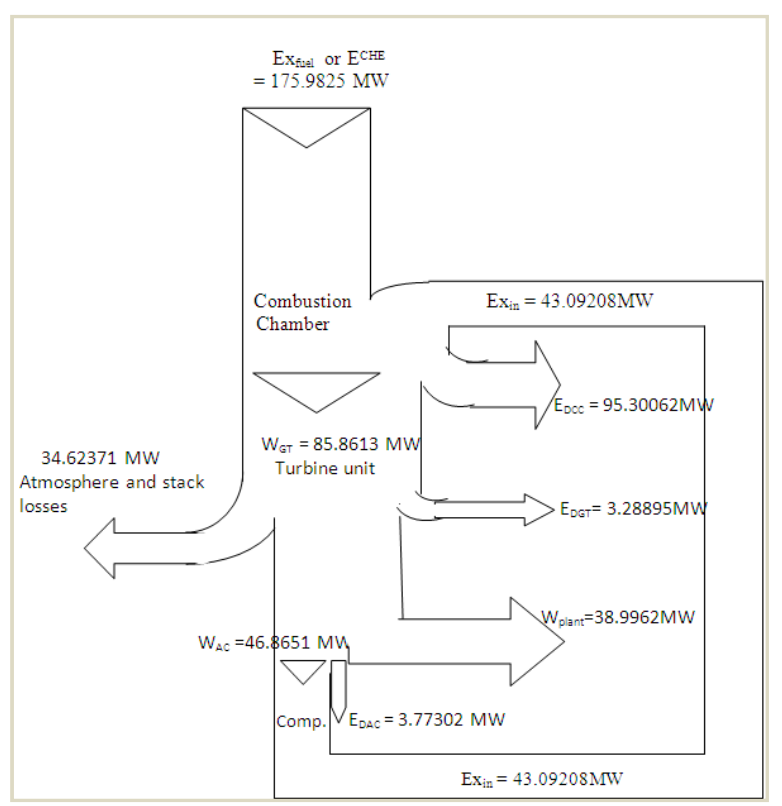

Figure 8. Exergy flow diagram for Omotosho Phase I

\subsection{Discussion}

From Table 3 and Figure 8, the exergy flow rate of the net power output of the various gas turbine power units is found from the exergy balance to be $38.9962 \mathrm{MW}$. The fuel exergy flow rate in the combustion chamber is found to be 175.9825 MW for the Plant. The total exergy destruction in the plant calculated $102.3626 \mathrm{MW}$.The gas turbine is found to have the highest exergy efficiency of $96.17 \%$ in the plant. The combustion chamber exergy efficiency is $45.46 \%$, which has the high - energy degradation and high irreversibility among the components considered. The exergy efficiency of the air compressor is $91.95 \%$ and largest is in the turbine section $96.17 \%$. The exergy efficiency of the overall plant is $41.83 \%$. The exergy efficiency for the plant and its various components are 
presented in Figure 3.

The exergy destruction efficiencies are presented in Figures 4 and 6, comparing the exergy destruction of the components of the gas power plant, the largest amount of the total exergy supplied in the plant is destroyed in the combustion chamber, the least exergy loss occurred in the gas turbine. It is observed that exergy destruction in the total plant is $58.17 \%$ of the total inlet exergy flow in the Omotosho Gas Power Plant as shown in Figure 4. The values of components and total plant exergy efficiency and exergy destruction efficiency are in the same range as in $[12,13,25]$ and disagree with [9] paper that stated the largest exergy destruction occurred in the turbine section.

Figure 5 compare the exergy efficiencies of the air compressor, combustion chamber, gas turbine and the overall plant of the GT at different ambient temperature values. The exergy efficiencies of the plant and the combustion chamber are found to decrease significantly with increase in the ambient temperature, while slight increase in the compressor and turbine exergy efficiency with increase in ambient temperature. When the gas turbine operates at varying ambient temperatures, the exergy loss at a lower ambient temperature is less than at a higher ambient temperature as shown in Figures 6. Figure 7 shows that the exergy efficiency of the plant increases steadily as the turbine inlet temperature increases, which agrees with what, was obtained in [11].

\section{Conclusion}

The exergy balance applied to each of the major components of Plant and to the overall plant revealed the amount of the total exergy generation and exergy destruction in the station. The results from the study also showed that considerable exergy destruction occurs in the combustion chamber; exergy efficiency, exergy destruction, power output depend on ambient temperature. Exergy efficiency increases with increase in the turbine inlet temperature.

\section{Nomenclature}

$\begin{array}{ll}\mathrm{C} & \begin{array}{l}\text { Compressor } \\ \text { CC }\end{array} \\ \mathrm{C}_{\mathrm{p}} & \begin{array}{l}\text { Specific heat capacity at constant } \\ \text { pressure }(\mathrm{kJ} / \mathrm{kgK})\end{array} \\ \mathrm{Ex} & \text { Exergy flow rate(MW) } \\ \mathrm{FLT} & \text { First law of thermodynamics } \\ \mathrm{GE} & \text { General Electric } \\ \mathrm{Gen} & \text { Generator unit } \\ \mathrm{GT} & \text { Gasturbine unit } \\ \mathrm{LHV} & \text { Lower heating value }(\mathrm{kJ} / \mathrm{kg}) \\ \dot{\mathrm{m}} & \text { Mass flow rate(kg/s) } \\ \mathrm{p} & \text { Pressure(bar) } \\ \mathrm{P} & \text { Power(MW) } \\ \mathrm{PHCN} & \text { Power Holding Company of } \\ \mathrm{Q} & \text { Nigeria } \\ & \text { Heatsupplied/removedrate(MW) }\end{array}$

\begin{tabular}{ll}
$\mathrm{R}$ & Universal gas constant $(\mathrm{kJ} / \mathrm{kgK})$ \\
$\mathrm{S}$ & Entropy flow rate $(\mathrm{MW} / \mathrm{K})$ \\
$\mathrm{S}$ & Specific entropy $(\mathrm{kJ} / \mathrm{kgK})$ \\
$\mathrm{SLT}$ & Second law of thermodynamics \\
$\mathrm{t}$ & Temperature $\left({ }^{0} \mathrm{C}\right)$ \\
$\mathrm{T}$ & Absolute temperature $(\mathrm{K})$ \\
$\mathrm{W}$ & Work done $(\mathrm{MW})$ \\
$\mathrm{GREEKSYMBOLS}$ & \\
$\gamma$ & Specific heat capacities ratio \\
$\varepsilon$ & Exergy efficiency \\
$\varepsilon_{\mathrm{D}}$ & Exergy destruction efficiency \\
$\mathrm{SUBSCRIPTS}$ & \\
$\mathrm{A}$ & Air \\
$\mathrm{AC}$ & Air compressor \\
$\mathrm{Amb}$ & Ambient \\
$\mathrm{CC}$ & Combustion chamber \\
$\mathrm{D}$ & Destruction \\
Exh & Exhaust \\
$\mathrm{F}$ & Fuel \\
$\mathrm{I}$ & In \\
$\mathrm{O}$ & Out \\
Ref & reference/ambient \\
$\mathrm{SUPERSCRIPTS}$ & \\
$\mathrm{M}$ & Material \\
$\mathrm{CHE}$ & Chemical \\
$\mathrm{P}$ & Mechanical \\
$\mathrm{T}$ & Thermal \\
& \\
\hline &
\end{tabular}

\section{References}

[1] Dincer J., Rosen M. A.: Exergy Energy, Environment and Sustainable Development, Exergy Hand Book, $1^{\text {st }}$ Edition, Elsevier. 2007

[2] Sue D. C, Chuang C. C.: Engineering Design and Exergy Analysis for Combustion Gas Turbine Based Power Generation System, Energy 2004, 29, pp 1183-1205

[3] ThringM.W.: The Virtue of Energy, Its' Meanings and Practical Significance, Journal Institute of Fuel 1944,Vol.17, pp116-123.

[4] Nishikawa K, Fujita Y., Hamhiko O.: Availability Accounting of A Steam Power Plant, Energy Developments in Japan 1984,Vol.7, pp17-57.

[5] Moran M.J.: Availability Analysis-A Guide to Efficient Energy Use, ASME Press, New York. 1989.

[6] Moran M.J., Shapiro H.N.: Fundamentals of Engineering Thermodynamics, $4^{\text {rd }}$ edition, John Wiley \& Sons, New York, 2000

[7] Ibrahim H., Mohd Z.Y., Mohd H.B.: Exergy Analysis of a 120MW Thermal Power Plant, A proceeding of the BSMEASME International Conferenceon Thermal Engineering, $31^{\text {st }}$ December 2001, Dhaka Bangkdash, pp177-182.

[8] Cengel Y.A and Boles M.A.: Thermodynamics-An Engineering Approach, $5^{\text {th }}$ edition, McGraw-Hill, Boston, 2006.

[9] Ofudu J.C., AbamD .S.P.: Energy analysis of Afam Thermal Power Plant, NSE Technical Transactions 2002,Vol.37,No.3. 
[10] Dincer I., Cengel Y.A: Energy, Entropy and Exergy Concepts and their Roles in Thermal Engineering, Entropy 2001,3,116-149.

[11] Abam D.S.P., Moses N.N.: Computer Simulation of Gas Turbine Performance, Global Journal of Researches in Engineering 2011, Vol.XI, IssueI, Version1.0. ISSN:09755861.

[12] Al-Doori W.H.A.: Exergy Analysis of as Turbine performance with Effect Cycle Temperature, IJRRAS201213(2)pp549-556.

[13] Ighodaro O.O., Aburime B.A.: Exergetic Appraisal of DeltaIV Power Station Ughelli. Journal of Engineering Trends in Engineering and Applied Sciences (JETEAS)20112(2):216-218.

[14] Mousafarash A., Ameri M.: Exergy and Exergo-Economic Based Analysis of a Gas Turbine Power Generation System, Journal of Power Technologies 201393(1)(2013)44-51.

[15] Egware H.O.: Exergy Analysis of OmotoshophaseI Gas Thermal Power Plant (M.Eng.Project), University of Benin. Nigeria.2013

[16] Ghazikhani M., Ahamadzadehtalatapeh M.: Experimantal Investigation of Exergy Destruction in an 8kW Power plant, Int.J. Energy Environ., 20101(5),815-822,2010.

[17] Kaushik S.C, Mishra R.D., Singh N.: Second Law Analysis of a Solar Thermal Power system. International Journal of Solar Energy 2000; 20:(2)39-53.

[18] LiorN., Zhang N.: Energy, Exergy and Second law performance Criteria. Energy 2007:32(2)81-96.
[19] Khaliq A., kaushik S.C.: Second-law Based Thermodynamic Analysis of Brayton/Rankine Combined Power Cycle with Reheat, Applied Energy 2004,Vol.78,No.2,pp179-197.

[20] Reddy V.S, KausihikS.C, TyagiS.K., Panwar N.L.: An Approach to Analyze Energy and Exergy Analysis of Thermal Power Plant: A Review, Smart Grid and Renewable Energy 20101,143-152.

[21] Ameri M., Enadi N.: Thermodynamic Modelling and Second Law Based Performance Analysis of a Gas Turbine Power Plant (Exergy and Exergoeconomic Analysis), Journal of Power Technologies 2012,92(3)183-191.

[22] Saravanamuttoo H., Roger G.F.C., Cohen H., Straznicky P.V.: Gas Turbine Theory, $6^{\text {th }}$ edition, Pearson Education Ltd, England,2009.

[23] Rogers G.F.C., Mayhew Y.R.: Thermodynamics and Transport Properties of Fluids, $5^{\text {th }}$ edition, Oxford Basic Black well publishers, Britain,(1995).

[24] Egware H.O, Obanor A.I,: Energy Analysis of Omotosho PhaseI Gas Thermal Plant, International Journal of Engineering \& Technology Sciences (IJETS)2013,1(4):206217.

[25] Ebadi M.J., Gorji-Brandy M.: Exergetic Analysis of Gas Turbine Plant, International Journal of Exergy 2005,Vol.2,No.1.

[26] Coplan C.O.: Exergy Analysis of Combined Cycle Cogeneration Systems(M.ScThesis), Department of Mechanical Engineering, Middle East Technical University, 2005. 